Jurnal SainHealth Vol. 3 No. 1 Edisi Maret 2019

(C) Fakultas Ilmu Kesehatan Universitas Maarif Hasyim Latif Sidoarjo

p-ISSN : 2548-8333

e-ISSN : 2549-2586

\title{
UJI AKTIVITAS ANTIBAKTERI FRAKSI DARI MASERAT Zibethinus folium TERHADAP Escherichia coli
}

\author{
Choirul Huda ${ }^{1}$, Amalia Eka Putri ${ }^{2}$, Devri Windi Sari ${ }^{3}$ \\ 1,2,3) Program Studi Farmasi, Sekolah Tinggi Ilmu Kesehatan Karya Putra Bangsa Tulungagung, Jalan Raya \\ Tulungagung-Blitar KM 4, Sumbergempol,Tulungagung \\ Email : hudacoy85@gmail.com
}

\begin{abstract}
Durian leaf (Zibethinus folium) is part of the plant that has antibacterial activity. The purpose of this study was to determine the antibacterial activity of Zibethinus folium fraction against Escherichia coli ATCC 25922 in vitro. The research method used is experimental. Leaf samples were extracted using maceration method with $70 \%$ ethanol and purified by fractionation methods using aqua distilled, n-hexane, and ethyl acetate. Positive control is clindamycin gel and negative control is 5\% DMSO. Statistical analysis was performed with One-Way Anova. Phytochemical screening results show that macerate Zibethinus folium contains flavonoids, tannins, saponins and steroids. The test results of antibacterial activity aqua distilled fraction and ethyl acetate fraction of macerate Zibethinus folium shows antibacterial activity against Escherichia coli ATCC 25922, while the n-hexane fraction of macerate Zibethinus folium showed no antibacterial activity against Escherichia coli ATCC 25922. aqua distilled fraction of $40 \%$ showed a response the most well barriers with zone of inhibition $8.33 \pm 0.76 \mathrm{~mm}$, meaning that aqua distilled fraction of $40 \%$ including medium category.
\end{abstract}

Keywords: Zibethinus folium, maceration, fractionation, antibacterial, Escherichia coli

\section{PENDAHULUAN}

Indonesia dikenal sebagai negara megabiodiversity dan menjadi salah satu pusat keanekaragaman hayati dunia (Suhartini, 2009). Keanekaragaman jenis tumbuhan Indonesia menempati urutan kedua di dunia setelah Brazil dan menduduki urutan terkaya pertama, jika biota laut ikut diperhitungkan. Spesies tumbuhan berkhasiat obat yang hidup di kepulauan Indonesia diketahui sekurang-kurangnya 9.600 spesies dan kurang lebih 300 spesies telah dimanfaatkan sebagai bahan baku pembuatan obat tradisional oleh industri obat tradisional (Depkes RI, 2007).

Obat tradisional adalah bahan atau ramuan bahan yang berupa bahan tumbuhan, bahan hewan, bahan mineral, sediaan sarian/galenik atau campuran dari bahan tersebut, yang berdasarkan pengalaman telah digunakan secara turun-temurun untuk pengobatan (BPOM, 2005). Tanaman asli Indonesia yang berpotensi sebagai obat salah satunya adalah daun durian (Insanu dkk., 2011).

Daun durian (Zibethinus folium) merupakan bagian tanaman yang mempunyai aktivitas antibakteri (Maradona, 2013). Daun durian mengandung senyawa flavonoid, tanin, steroid dan saponin (Kandoli dkk., 2016; Maradona, 2013). Menurut Penelitian Chigurupati dkk. (2017) menunjukkan bahwa daun durian mempunyai aktivitas antibakteri terhadap Escherichia coli. 
Jurnal SainHealth Vol. 3 No. 1 Edisi Maret 2019

(C) Fakultas Ilmu Kesehatan Universitas Maarif Hasyim Latif Sidoarjo

p-ISSN : 2548-8333

e-ISSN : 2549-2586

Escherichia coli merupakan bakteri yang sering menyebabkan infeksi pada manusia. Escherichia coli termasuk flora normal pada sistem pencernaan manusia yang mempunyai peranan penting pada fungsi normal intestinal dan nutrisi, namun bila mencapai jaringan di luar intestinal bakteri ini akan menjadi patogen (Noviana, 2004). Obat yang paling banyak digunakan pada infeksi akibat bakteri adalah antibiotik (Menkes RI, 2011).

Antibiotik mempunyai dua efek utama, yaitu secara terapeutik mampu menyerang organisme infeksius dan juga mengeliminasi bakteri lain yang bukan penyebab penyakit (Amin, 2014). Klindamisin adalah antibiotik turunan linkomisin yang bekerja dengan meghambat sintesis protein (Katzung dkk., 2012). Klindamisin terutama bermanfaat untuk infeksi kuman anaerob dalam penggunaan klinik (Gunawan, 2012). Aktivitas antibakteri klindamisin sama halnya yang ditunjukkan pada senyawa kimia flavonoid, saponin, tanin, dan steroid yang terkandug dalam daun durian. Menurut Widjaja dkk. (2014), kegunaan bahan tumbuhan sebagai bahan obat bertumpu pada kandungan senyawa bioaktif yang diproduksi oleh sel-sel tumbuhan tersebut di dalam sistem jalur biosintesis metabolit sekundernya. Senyawa-senyawa aktif tersebut dapat dipisahkan dari tanamannya melalui proses yang disebut dengan ekstraksi.

Maserasi merupakan prosedur pemisahan dengan menggunakan pelarut yang dilakuakan pada suhu kamar dan disertai dengan pengocokan beberapa kali (Depkes RI, 2000). Keuntungan metode maserasi yaitu, prosedur dan peralatan yang digunakan sederhana, senyawa aktif tidak terurai karena proses ekstraksi dilakukan tanpa pemanasan (Nurhasnawati dkk., 2017). Maserat yang dihasilkan merupakan campuran dari berbagai senyawa. Oleh karena itu, diperlukan fraksinasi untuk memisahkan golongan utama kandungan yang satu dari golongan lainnya.
Fraksinasi merupakan suatu proses pemisahan senyawa berdasarkan perbedaan kepolaran (Harborne, 2006). Menurut Nwodo dkk. (2011), fraksinasi dari maserat tumbuhan atau pemurnian zat aktif pada prinsipnya mampu mengoptimalkan potensi dan memperluas spektrum aktivitasnya.

Berdasarkan latar belakang diatas, penulis ingin mengetahui aktivitas antibakteri fraksi Zibethinus folium dalam menghambat pertumbuhan bakteri Escherichia coli, yaitu salah satu bakteri penyebab infeksi.

\section{METODE PENELITIAN}

\section{Alat dan Bahan}

Alat yang digunakan dalam penelitian ini adalah gunting, blender, ayakan mesh 60, dan neraca analitik untuk pembuatan simplisia. Botol kaca coklat, corong kaca, kain mori, oven dan beaker glass untuk pembuatan maserat. Neraca analitik, botol timbang, sendok tanduk dan oven untuk uji kadar air. Tabung reaksi, pipet ukur, beaker glass, pipet tetes, stop watch, corong pisah, corong kaca, kertas saring dan beaker glass untuk skrining fitokimia dan fraksinasi. Autoklaf (GEA YX2808) cawan petri, kertas cakram, erlenmeyer, tabung reaksi, alumunium foil, mikropipet, rak tabung reaksi, lampu spiritus, Laminar Air Flow (ESCO EMC 600), ose, bunsen, kapas, dan inkubator (Model DNP Electro Thermal Incubator) untuk uji aktivitas antibakteri.

Bahan yang digunakan dalam penelitian ini adalah daun durian segar sebanyak $5 \mathrm{~kg}$ untuk pembuatan simplisia, serbuk daun durian $500 \mathrm{~g}$ dan etanol $70 \% 2500 \mathrm{ml}$ untuk pembuatan maserat. Maserat daun durian, n-heksan, etil asetat, etanol, klorofom, asam asetat glasial, $\mathrm{H}_{2} \mathrm{SO}_{4}$ pekat, $\mathrm{Mg}, \mathrm{HCl}$, dan $\mathrm{FeCl}_{3} 1 \%$ untuk uji bebas etanol, skrining fitokimia dan fraksinasi. Nutrient agar (NA), nutrient broth (NB), aqua destilata, eosin methylene blue agar (EMBA), Escherichia coli, $\mathrm{NaCl}$ fisiologis, fraksi daun 
Jurnal SainHealth Vol. 3 No. 1 Edisi Maret 2019

(C) Fakultas Ilmu Kesehatan Universitas Maarif Hasyim Latif Sidoarjo

p-ISSN : 2548-8333

e-ISSN : $2549-2586$

durian, klindamisin dan DMSO untuk uji aktivitas antibakteri.

\section{Prosedur Penelitian}

\section{Determinasi Tanaman}

Sampel tanaman daun durian diidentifikasi di di Materia Medica Batu Malang untuk mengetahui morfologi daun durian (Zybethinus folium).

\section{Pembuatan Simplisia}

Pembuatan simplisia daun durian dilakukan dengan mengumpulkan daun muda sampai tua yang dipetik secara langsung. Daun durian kemudian disortasi basah yang bertujuan untuk membersihkan daun dari kotoran dan benda asing. Tahap selanjutnya dilakukan pencucian sebanyak tiga kali, menggunakan air bersih dari sumur secara mengalir untuk menghilangkan tanah atau pengotor lain yang melekat dan ditiriskan. Proses berikutnya dilakukan pengeringan dengan cara diangin-anginkan sampai kering dan dilakukan sortasi kering (Depkes RI, 1985).

\section{Pembuatan Maserat}

Simplisia yang diperoleh dihaluskan dengan blender dan diayak dengan ayakan nomor 60. Serbuk simplisia ditimbang seberat $500 \mathrm{~g}$. Serbuk yang telah ditimbang kemudian dimaserasi menggunakan pelarut etanol 70\% sebanyak $2500 \mathrm{ml}$ selama 72 jam. Filtrat kemudian disaring menggunakan kain mori rangkap dua. Filtrat hasil saringan diuapkan dengan oven pada suhu $70^{\circ} \mathrm{C}$ untuk mendapatkan maserat (Kandoli dkk., 2016).

\section{Uji Kadar Air}

Uji kadar air serbuk simplisia dilakukan dengan memasukkan kurang lebih $10 \mathrm{~g}$ simplisia dan ditimbang seksama dalam wadah yang telah ditara. Dikeringkan pada suhu $105^{\circ} \mathrm{C}$ selama 5 jam (Depkes RI, 2000). Kadar air pada simplisia adalah tidak lebih dari 10\% (BPOM RI, 2014).

\section{Skrining Fitokimia \\ Tanin}

Sampel sebanyak $2 \mathrm{~g}$ ditambah etanol sampai semua sampel terendam. Kemudian sebanyak $1 \mathrm{ml}$ larutan sampel ditambahkan 2-3 tetes larutan $\mathrm{FeCl}_{3} 1 \%$. Terbentuknya warna hitam kebiruan atau hijau menunjukkan hasil positif (Harborne, 2006).

\section{Flavonoid}

Sampel sebanyak $\pm 1 \mathrm{ml}$ dicampur dengan $3 \mathrm{ml}$ etanol 70\%, lalu dikocok, dipanaskan, dan dikocok lagi kemudian disaring. Filtrat yang diperoleh, kemudian ditambah $\mathrm{Mg}$ 0,1 g dan 2 tetes $\mathrm{HCl}$ pekat. Terbentuknya warna merah, orange, dan hijau menunjukkan adanya flavonoid (Harborne, 2006).

\section{Saponin}

Sampel sebanyak $\pm 1 \mathrm{ml}$ dididihkan dengan $10 \mathrm{ml}$ aqua destilata dalam penangas air. Filtrat dikocok dan didiamkan selama 15 menit. Terbentuknya busa yang stabil berarti positif terdapat saponin (Harborne, 2006).

\section{Steroid}

Sampel sebanyak $\pm 1 \mathrm{ml}$ dicampur dengan $3 \mathrm{ml}$ kloroform atau $3 \mathrm{ml}$ etanol $70 \%$ dan ditambah $2 \mathrm{ml}$ asam sulfat pekat dan $2 \mathrm{ml}$ asam asetat anhidrat (reagen Liebermann-Burchard). Positif steroid ditunjukkan dengan terbentuknya warna hijau (Harborne, 2006).

\section{Fraksinasi}

Maserat sebanyak $5 \mathrm{~g}$ dilarutkan dalam aqua destilata sebanyak $25 \mathrm{ml}$. Ditambahkan 25 $\mathrm{ml}$ n-heksan, dikocok dan dipisahkan fraksi aqua destilata dengan fraksi n-heksan. Dimasukkan aqua destilata yang telah disari ke dalam corong pisah, ditambahkan $25 \mathrm{ml}$ etil asetat, dikocok dan dipisahkan fraksi aqua destilata dengan fraksi etil asetat. Dilakukan 3 kali penyarian pada masingmasing fraksi dengan penambahan jumlah pelarut yang sama (Harborne, 2006). Filtrat hasil saringan diuapkan dengan oven pada suhu $60^{\circ} \mathrm{C}$. 
Jurnal SainHealth Vol. 3 No. 1 Edisi Maret 2019

(C) Fakultas Ilmu Kesehatan Universitas Maarif Hasyim Latif Sidoarjo

p-ISSN : 2548-8333

e-ISSN : $2549-2586$

\section{Uji Aktivitas Antibakteri Fraksi Zibethinus}

\section{folium}

Uji aktivitas antibakteri fraksi daun durian menggunakan metode difusi. Disiapkan media yang telah diinokulasi dengan bakteri. Fraksi daun durian dengan seri konsentrasi 15\%, 30\%, dan 40\% ditambahkan pada masing-masing cakram steril sejumlah 10 mikroliter. Kertas cakram steril yang telah diresapi dengan fraksi Zibethinus folium ditempatkan pada permukaan media dengan pinset steril dan ditekan dengan lembut kebawah untuk memastikan kontak antara kertas cakram dengan permukaan media. Kontrol positif digunakan klindamisin, Sedangkan kontrol negatif digunakan dimethylsulfoxide (DMSO) 5\%. Cawan petri diinkubasi selama 24 jam pada suhu $37^{\circ} \mathrm{C}$. Diamati dan diukur diameter zona hambat (Jayaprakash \& Nagarajan, 2016).

\section{HASIL DAN PEMBAHASAN}

Daun durian diperoleh dari desa Sumberdadi Kecamatan Sumbergempol Kabupaten Tulungagung, Jawa Timur. Hasil determinasi menunjukkan bahwa bahan yang digunakan untuk penelitian adalah jenis daun durian dengan nama ilmiah Durio zibethinus Murr.

Penetapan kadar air simplisia dilakukan secara gravimetri. Tujuannya adalah untuk mengetahui besarnya kandungan air pada simplisia, terkait dengan kemurnian dan kontaminasi yang mungkin terjadi (Depkes RI, 2000). Hasil penelitian menunjukkan persentase kadar air Zibethinus folium sebesar 3,1\%. Menurut BPOM RI (2014), kandungan air simplisia adalah tidak lebih dari 10\%. Hal ini bertujuan untuk menghindari pertumbuhan jamur dalam simplisia karena reaksi enzimatik tidak berlangsung bila kadar air dalam simplisia $<10 \%$ (Depkes RI, 1985).

Skrining fitokimia maserat Zibethinus folium bertujuan untuk memastikan keberadaan seyawa metabolit sekunder yang terkandung dalam daun durian (Harborne, 2006). Hasil penelitian menunjukkan bahwa maserat Zibethinus folium positif mengandung saponin, flavonoid, steroid, dan tanin seperti yang disajikan pada Tabel 1 .

Tabel 1. Hasil skrining fitokimia

\begin{tabular}{lcl}
\hline Golongan & Hasil & \multicolumn{1}{c}{ Keterangan } \\
\hline Flavonoid & + & Terbentuknya warna Jingga \\
Saponin & + & Terbentuk busa yang stabil \\
Steroid & + & Terbentuknya warna hijau \\
Tanin & + & $\begin{array}{l}\text { Terbentuknya warna hitam } \\
\text { kebiruan }\end{array}$ \\
\hline
\end{tabular}

Uji aktivitas antibakteri fraksi Zibethinus folium terhadap Escherichia coli ATCC 25922 dilakukan untuk mengetahui efektivitas Zibethinus folium sebagai antibakteri. Hasil penelitian pada Gambar 1 menunjukkan bahwa fraksi n-heksan tidak mempunyai aktivitas antibakteri karena senyawa steroid yang tertarik pada fraksi n-heksan tidak membentuk zona bening disekitar cakram, artinya tidak ada respon hambatan (Pratiwi, 2008). Hal tersebut diduga karena sedikitnya kandungan senyawa non polar pada maserat Zibethinus folium, yaitu hanya terdapat senyawa steroid.

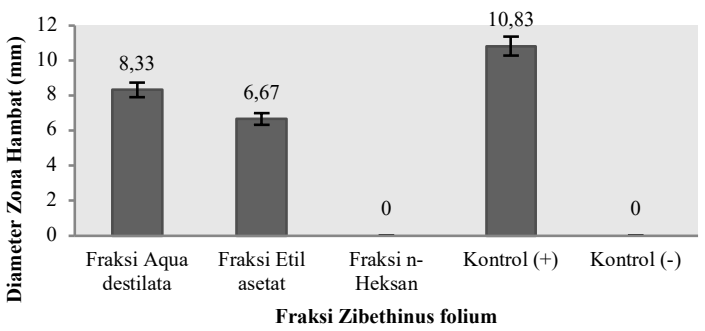

Gambar 1. Diameter zona hambat fraksi Zibethius folium terhadap Escherichia coli ATCC 25922

Fraksi aqua destilata dan fraksi etil asetat mempunyai aktivitas antibakteri yang ditandai dengan terbentuknya zona bening disekitar kertas cakram (Pratiwi, 2008). Aktivitas antibakteri yang ditunjukkan oleh fraksi aqua destilata dan efraksi etil asetat ditimbulkan oleh kandungan 
Jurnal SainHealth Vol. 3 No. 1 Edisi Maret 2019

(C) Fakultas Ilmu Kesehatan Universitas Maarif Hasyim Latif Sidoarjo

p-ISSN : 2548-8333

e-ISSN : $2549-2586$

metabolit sekunder yang bekerja secara sinergis, yaitu senyawa steroid, flavonoid, tanin, dan saponin.

Flavonoid memberikan respon hambatan dengan mengganggu keutuhan membran sel bakteri oleh adanya pembentukan senyawa kompleks dari protein ekstraseluler dengan flavonoid (Kumar \& Pandey, 2013). Tanin sebagai antibakteri bekerja berdasarkan kemampuannya mempresipitasi protein, karena tanin mempunyai efek yang sama dengan fenolik (Courtney dkk., 2016).

Aktivitas saponin sebagai antibakteri ditunjukkan oleh mekanisme penurunan tegangan permukaan dinding sel bakteri. Akibatnya sel bakteri akan mengalami kebocoran sehingga mengakibatkan kematian sel (Ngajow dkk., 2013). Steroid dilaporkan memiliki sifat antibakteri, korelasi antara membran lipid dan sensitivitas senyawa steroid menunjukkan mekanisme dimana steroid menyebabkan kebocoran liposom (Shihabudeen dkk., 2010).

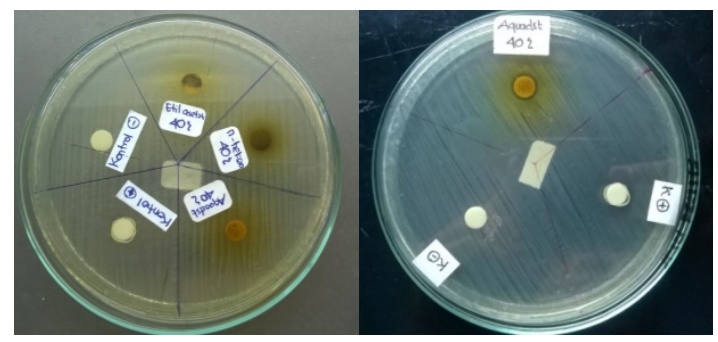

Gambar 2. Diameter zona hambat fraksi Zibethinus folium terhadap Escherichia coli ATCC 25922

Berdasarkan hasil orientasi dengan variasi konsentrasi $15 \%$, 30\%, dan $40 \%$, fraksi dengan seri konsentrasi $40 \%$ menunjukkan respon hambatan yang paling optimum seperti yang disajikan pada Gambar 2. Fraksi aqua destilata $40 \%$ dari maserat Zibethinus folium mampu menghambat pertumbuhan bakteri Escherichia coli ATCC 25922 dengan rata-rata diameter zona hambatnya sebesar $8,33 \mathrm{~mm}$, Sedangkan fraksi etil asetat $40 \%$ dari maserat Zibethinus folium mempunyai rata-rata diameter zona hambat sebesar $6,67 \mathrm{~mm}$ artinya respon hambatan dari fraksi aqua destilata dan fraksi etil asetat dari maserat Zibethinus folium termasuk kategori sedang karena diameter zona hambatnya masuk dalam rentang 5-10 (David \& Stout, 1971). Menurut Jawetz dkk. (2005), kinerja senyawa antibakteri dipengaruhi oleh struktur dinding sel bakteri. Pelczar dan Chan (2005) menyatakan struktur dinding sel bakteri Gram negatif relatif lebih kompleks karena tersusun dari tiga lapisan, yaitu lipoprotein, lipopolisakarida, dan peptidoglikan sehingga ketahanan senyawa antimikroba terhadap Escherichia coli lebih baik dibandingkan dengan bakteri Gram positif.

Klindamisin sebagai kontrol positif mempunyai rata-rata diameter zona hambat sebesar 10,83 $\mathrm{mm}$ artinya respon hambatan dari kontrol positif termasuk kategori kuat. Klindamisin digunakan sebagai kontrol positif karena aktivitas antibakteri klindamisin sama halnya yang ditunjukkan pada senyawa kimia yang terkandug dalam Zibethinus folium. Menurut Katzung dkk. (2012), klindamisin bekerja dengan meghambat sintesis protein. DMSO 5\% yang digunakan sebagai kontrol negatif tidak menunjukkan respon hambatan terhadap Escherichia coli. Alasan DMSO digunakan sebagai kontrol negatif karena DMSO merupakan pelarut yang dapat melarutkan hampir semua senyawa polar maupun non polar (Assidqi dkk., 2012). DMSO juga tidak bersifat bakterisidal sehingga dapat dipastikan bahwa aktivitas antibakteri murni dari fraksi Zibethinus folium tanpa pengaruh pelarutnya (Reynolds, 1996).

Menurut penelitian Maradona (2013) maserat Zibethinus folium tidak mampu menghambat pertumbuhan Escherichia coli. Penelitian lain menyebutkan bahwa ekstrak Zibethinus folium 0,01\% mampu menghambat pertumbuhan Escherichia coli dengan rata-rata diameter zona hambat sebesar $12 \mathrm{~mm}$ 
Jurnal SainHealth Vol. 3 No. 1 Edisi Maret 2019

(C) Fakultas Ilmu Kesehatan Universitas Maarif Hasyim Latif Sidoarjo

p-ISSN : 2548-8333

e-ISSN : 2549-2586

(Chigurupati et al., 2017). Perbedaan hasil yang didapatkan diakibatkan karena perbedaan metode yang digunakan, yaitu Maradona (2013) menggunakan metode maserasi, Sedangkan Chigurupati et al. (2017) menggunakan metode perkolasi. Berdasarkan penelitian yang telah dilakukan, fraksi aqua destilata dan fraksi etil asetat dari maserat Zibethinus folium mempuyai aktivitas antibakteri terhadap Escherichia coli. Hal tersebut membuktikan bahwa fraksinasi dari maserat tumbuhan atau pemurnian zat aktif pada prinsipnya mampu mengoptimalkan potensi dan memperluas spektrum aktivitas maserat tumbuhan (Nwodo et al., 2011).

Analisa hasil pada penelitian ini dilakukan dengan menggunakan One-Way Anova. Hasil analisis menunjukkan bahwa Sig 0,001 <0,05 maka $\mathrm{H}_{0}$ ditolak, artinya ketiga fraksi dari maserat Zibethinus folium, kontrol positif, dan kontrol negatif menunjukkan adanya perbedaan pada diameter zona hambat yang dihasilkan. Berdasarkan analisis dengan Pos Hoc Test diketahui bahwa antara fraksi aqua destilata, fraksi n-heksan, dan fraksi etil asetat dari maserat Zibethinus folium, serta kontrol positif dan kontrol negatif terdapat variabel yang sama yaitu fraksi n-heksan dengan kontrol negatif yang sama-sama tidak memiliki aktivitas antibakteri terhadap bakteri Escherichia coli ATCC 25922.

\section{KESIMPULAN DAN SARAN}

Berdasarkan hasil penelitian dapat disimpulkan bahwa:

1. Fraksi aqua destilata $40 \%$ dan fraksi etil asetat $40 \%$ dari maserat Zibethinus folium mempunyai aktivitas antibakteri terhadap Escherichia coli ATCC 25922, Sedangkan fraksi n-heksan dari maserat Zibethinus folium tidak mempunyai aktivitas antibakteri terhadap Escherichia coli ATCC 25922 secara in vitro.

2. Fraksi aqua destilata $40 \%$ menunjukkan respon hambatan paling optimum dengan rata- rata diameter zona hambat sebesar $8,33 \mathrm{~mm}$ terhadap Escherichia coli ATCC 25922 secara in vitro.

Adapun saran dalam penelitian ini adalah sebagai berikut:

1. Perlu dilakukan penelitian lebih lanjut dengan menggunakan metode isolasi yang berbeda.

2. Perlu dilakukan penelitian lebih lanjut dengan menggunakan jenis bakteri yang berbeda agar diketahui aktivitas antibaketi Zibethinus folium secara luas.

\section{DAFTAR PUSTAKA}

Amin, L.Z., 2014. Pemilihan Antibiotik yang Rasional. Medicinus, 27(3), pp.40-45.

Assidqi, K., Tjahjaningsih, W. \& Sigit, S., 2012. Potensi Ekstrak Daun Patikan Kebo (Euphorbia hirta) sebagai Antibakteri Terhadap Aeromonas hydrophila. Journal of Marine and Coastal Science, 1(2), pp.113-24.

BPOM, 2005. Peraturan Kepala Badan Pengawas Obat dan Makanan Republik Indonesia Nomor:HK.00.05.41.1384 Tahun 2005 Tentang Kriteria dan Tata Laksana Pendaftaran Obat Tradisional, Obat Herbal Terstandar dan Fitofarmaka. Jakarta: Badan Pengawas Obat dan Makanan Republik Indonesia.

Chigurupati, S. dkk., 2017. Quantitative Estimation and Antimicrobial Potential of Ethanol Extract of Durio zibethinus Murr. Leaves. Asian Journal of Pharmaceutical and Clinical Research, 10(9), pp.251-54.

Courtney, R., Sirdaarta, J., Matthews, B. \& Cock, I.E., 2016. Tannin Components and Inhibitory Activity of Kakadu Plum Leaf Extracts Against Microbial Triggers of Autoimmune Inflammatory Diseases. Pharmacognosy Journal, 7(1), pp.18-31.

David, W.W. and Stout, T.R. 1971. Disc Plate Method of Microbiological Antibiotic Assay. Microbiology. 22(4): 659-665. 
Jurnal SainHealth Vol. 3 No. 1 Edisi Maret 2019

(C) Fakultas Ilmu Kesehatan Universitas Maarif Hasyim Latif Sidoarjo

p-ISSN : 2548-8333

e-ISSN : $2549-2586$

Depkes RI, 1985. Cara Pembuatan Simplisia. Jakarta: Departemen Kesehatan RI.

Depkes RI, 2000. Parameter Standar Umum Ekstrak Tumbuhan Obat. Jakarta: Diktorat Jendral POM-Depkes RI.

Depkes RI, 2007. Kebijakan Obat Tradisional Tahun 2007. Jakarta: Departemen Kesehatan RI.

Harborne, J.B., 2006. Metode Fitokimia Penuntun Cara Modern Menganalisis Tumbuhan. Bandung : Penerbit ITB. Hal: 7-8, 69-71, 102-104, 155.

Insanu, M., Ruslan, K., Fidrianny, I. \& Wijaya, S., 2011. Isolasi Flavonoid dari Daun Durian (Durio Zibethinus Murr., Bombacaceae). Acta Pharmaceutica Indonesia, 34(1 \& 2), pp.6-10.

Jawetz, Melnick \& Adelberg's, 2005. Mikrobiologi Kedokteran. Jakarta : Salemba Medika. Hal: 233, 235.

Jayaprakash, S.B. \& Nagarajan, N., 2016. Studies on The Bioactive Compounds and Antimicrobial Activities of Medicinal Plant Centella asiatica (Linn). Journal of Medicinal Plants Studies, 4(5), pp.181-85.

Kandoli, F., Abijulu, J. \& Leman, M., 2016. Uji Daya Hambat Ekstrak Daun Durian (Durio zybethinus) terhadap Pertumbuhan Candida albicans secara In Vitro. PHARMACON Jurnal Ilmiah Farmasi, 5(1), pp.46-52.

Katzung, B.G., Masters, S.B. \& Trevor, A.J., 2012. Basic \& Clinical Pharmacology. 12th Ed. United States: McGraw-Hill Companies.

Kumar, S. \& Pandey, A.K., 2013. Chemistry and Biological Activities of Flavonoids: An Overview. The ScientificWorld Journal, 29, pp.1-16.

Maradona, D., 2013. Uji Aktivitas Antibakteri Ekstrak Etanol Daun Durian (Durio zybethinus L), Daun Lengkeng, (Dimocarphus longan Lour), dan Daun Rambutan (Nephelium lappaceum L) terhadap Bakteri Staphylococcus aureus ATCC 25925 dan Escherichia coli ATCC 25922. Skripsi. Jakarta: Fakultas Kedokteran UIN Syarif Hidayatullah.

Ngajow, M., Abidjulu, J. \& Kamu, V.S., 2013. Pengaruh Antibakteri Ekstrak Kulit Batang Matoa (Pometia pinnata) terhadap Bakteri Staphylococcus aureus secara In vitro. Jurnal MIPA UNSTRAT, 2(2), pp.128-32.

Noviana, H., 2004. Pola Kepekaan Antibiotika Escherichia coli yang Diisolasi dari Berbagai Spesimen Klinis. J Kedokteran Trisakti, 23(4), pp.122-26.

Nwodo, U.U. dkk., 2011. Effects of Fractionation and Combinatorial Evaluation of Tamarindus indica Fractions for Antibacterial Activity. Molecules, 16, pp.4818-27.

Peraturan Menteri Kesehatan Republik Indonesia Nomor 2406/MENKES/PER/XII/2011. Pedoman Umum Penggunaan Antibiotik. 1 Desember 2011. Berita Negara Republik Indonesia Tahun 2011 Nomor 874. Jakarta.

Pelczar Michael J. \& Chan E.C.S. 2005. DasarDasar Mikrobiologi 1. Jakarta: UI Press. Hal: 711-712 dan 867-868.

Pratiwi, S.T., 2008. Mikrobiologi Farmasi. Jakarta: Penerbit Erlangga. Hal: 188-191, 135-137.

Reynolds, J. E. F. 1996. Martindale, The Extra Pharmacopeia 31th Edition. The Royal Pharmaceutical Society Press. London. $p$ : $114-117$.

Shihabudeen, M.S., H, H.P.D. \& Thirumurugan, K., 2010. Antimicrobial Activity and Phytochemical Analysis of Selected Indian Folk Medicinal Plants. International Journal of Pharma Sciences and Research, 1(10), pp.430-34.

Suhartini, 2009. Peran Konservasi Keanekaragaman Hayati dalam Menunjang Pembangunan yang Berkelanjutan. Prosiding Seminar Nasional Penelitian. 
Jurnal SainHealth Vol. 3 No. 1 Edisi Maret 2019

C Fakultas Ilmu Kesehatan Universitas Maarif Hasyim Latif Sidoarjo

p-ISSN : 2548-8333

e-ISSN : 2549-2586

Yogyakarta, 2009. Jurusan Pendidikan

Biologi FMIPA Universitas Negeri

Yogyakarta.

Sujarweni, V.W., 2012. SPSS untuk Paramedis.

Yogyakarta: Gava Medika. Hal: 16-17, 31-

35, 141-146.

Widjaja, E.A. dkk., 2014. Kekinian

Keanekaragaman Hayati Indonesia.

Jakarta: LI 